\title{
Law and Sovereignty of the State in the Renegotiation of Freeport Contracts in Papua*
}

\author{
Khamami Zada, ${ }^{1}$ Mustolih, ${ }^{2}$ Diana Mutia Habibaty, ${ }^{3}$ Lukman Hakim, ${ }^{4}$ \\ Desy Purwaningsih, ${ }^{5}$ Trini Diyani ${ }^{6}$ \\ Universitas Islam Negeri Syarif Hidayatullah Jakarta
}

10.15408/jch.v9i2.21546

\begin{abstract}
The mineral and coal mines have long been managed by foreign contracts between governments and foreigners. The position threatens the state's sovereignty over the wealth of natural resources. The study was to analyze the renege-management of Indonesia's Freeport mines in Papua. Socio-legal methods were used to analyze the renegotiation of Indonesia's Freeport management. The study found that according to the principle of state mastery over natural resources as a common property of Indonesian people's prosperity as in article 33 verses (3) constitution of 1945, the Indonesian government officially took over its 51-percent share of Freeport. It is part of an expression of national sovereignty over the management of its natural resources. With this position, Freeport's mining management is no longer based on a contract of work, but a Special Mining Business License which provides guarantees to business holders to have their licenses extended to provide certainty to mining business actors in conducting mining business in Indonesia.
\end{abstract}

Keywords: Renegotiation; Freeport; State Sovereignity

* Received: May 2, 2021, revised: June 8, 2021, accepted: June 17, 2021, Published: 31 August, 2021.

1 Lecturer in Faculty of Sharia and Law, Syarif Hidayatullah State Islamic University Jakarta. Email: khamami@uinjkt.ac.id

2 Lecturer in Faculty of Sharia and Law, Syarif Hidayatullah State Islamic University Jakarta. Email: mustolih@uinjkt.ac.id

${ }^{3}$ Lecturer in Faculty of Sharia and Law, Syarif Hidayatullah State Islamic University Jakarta. Email: diana.mutia@uinjkt.ac.id

${ }^{4}$ Researcher in Faculty of Sharia and Law, Syarif Hidayatullah State Islamic University Jakarta. Email: cipopalpacino@gmail.com

${ }^{5}$ Researcher in Faculty of Sharia and Law, Syarif Hidayatullah State Islamic University Jakarta. Email: desypurwaningsih.dp@gmail.com

6 Researcher in Faculty of Sharia and Law, Syarif Hidayatullah State Islamic University Jakarta. Email: diyanitrini@gmail.com 


\title{
Hukum dan Kedaulatan Negara Dalam Renegosiasi Kontrak Freeport Di Papua
}

\begin{abstract}
Abstrak
Pertambangan mineral dan batubara selama ini dikelola pihak asing berdasarkan kontrak antara pemerintah dan pihak asing. Posisi ini sesungguhnya mengancam kedaulatan negara atas kekeyaaan sumberdaya alam. Studi ini bertujuan untuk menganalisis renegosiasi pengelolaan tambang PT Freeport Indonesia di Papua. Metode socio-legal digunakan untuk menganalisis renegosiasi pengelolaan tambang PT Freeport Indonesia. Studi ini menemukan bahwa berdasarkan prinsip penguasaan negara atas sumberdaya alam sebagai common property bangsa Indonesia untuk kemakmuran rakyat sebagaimana pasal 33 ayat (3) Undang-Undang Dasar 1945, Pemerintah Indonesia secara resmi mengambil alih saham PT. Freeport Indonesia sebesar 51 \%. Kebijakan ini merupakan bagian dari perwujudan kedaulatan negara atas pengelolaan sumberdaya alamnya. Dengan posisi ini, pengelolaan tambang Freeport bukan lagi berdasarkan kontrak karya, melainkan Izin Usaha Pertambangan Khusus yang memberikan jaminan kepada pemegang usaha untuk diperpanjang izinnya unutk memberikan kepastian kepada pelaku usaha pertambangan dalam melakukan bisnis pertambangan di Indonesia.
\end{abstract}

Kata Kunci: Renegosiasi; Freeport; Kedaulatan Negara

\section{Закон и суверенитет государства при пересмотре договоров Freeport в Папуа}

\begin{abstract}
Аннотация
До настоящего времени управление добычей полезных ископаемых и угля осуществлялось иностранными сторонами на основании договоров между правительством и иностранными сторонами. Эта позиция фактически угрожает суверенитету государства над богатством природных ресурсов. Данное исследование направлено на анализ пересмотра условий руководства рудником компании Freeport Indonesia в Папуа. Социально-правовой метод был использован для анализа пересмотра условий руководства рудником компании Freeport Indonesia. Это исследование показало, что на основе принципа государственного контроля над природными ресурсами как общей собственностью индонезийского народа для процветания народа, как указано в пункте (3) статьи 33 Конституции 1945 года, правительство Индонезии официально приняло на себя акции из компании Freeport Indonesia на $51 \%$. Эта политика является частью реализации государственного суверенитета над управлением своими природными ресурсами. С этой должностью управление горнодобывающей промышленностью Freeport больше не основывается на договоре на выполнение работ, а на специальной лицензии на горнодобывающий бизнес, которая предоставляет владельцам бизнеса гарантии продления их лицензий, чтобы обеспечить уверенность участников горнодобывающего бизнеса в ведении горнодобывающего бизнеса в Индонезии.
\end{abstract}

Ключевые Слова: Пересмотр; Freeport; Государственный суверенитет 


\section{A. INTRODUCTION}

Indonesia has immense natural wealth, such as coal, gold, silver, and nickel. But to manage it requires considerable human resources and resources. In the second quarter of 2008, bank Indonesia the Central Bank decided to raise its key rate by 25 basis points to 8.25 percent. Understandably, if the copper, gold, and silver mines in Mimika province of Papua are not self-managed by Indonesia, instead are dealt with by Freeport Indonesia (which is then called Freeport) which is a contract-based subsidiary of Freeport-Mc Moran Copper \& Gold Inc., which refers to the contract work scheme by section 8 (1) the 1967 rule number 1 on the transfer of foreign capital states: "Foreign investment in mining is based on an agreement with the Indonesian government on a lease of work or other forms following current regulations of the law." It is possible to engage foreign investors in Indonesia's mining operations (Hertanto, 2003). In this position, the political direction of state law does not hold the principle of state sovereignty over natural resources. Mining management is instead handed over to foreign private companies that are on par with the Indonesian government with very large financial gains, such as an imbalance in profit sharing and in bargaining position, manipulation, abuse of office and corruption in contract making, environmental damage, and public objections (Redi, 2016a).

National leadership since the reformation failed to take care of Freeport for sovereignty over the management of natural resources. According to the constitutional court of number 002/ PUU-I /2003, natural resource use through license was under article 33 of the 1945 constitution and was not a silver contract. The contract regime has placed the government's position in a state of secondary importance as a result of the state's subprime mortgage of state assets, which in turn lose its sovereignty in managing natural resources. The relationship between countries and private was not the intellectual one; it was the public one that permitted them. According to this, his Freeport contract directly contradicted article 33 of the 1945 constitution as it was a matter of concern over the right to state control (Redi, 2016)

For decades, the Contract of Work was almost undisputed, until the awareness of the Indonesian people about natural resources emerged to reorganize the management of natural resources, including reviewing various contracts of work in the mining sector. The Indonesian government seems to have responded to this pressure by issuing policies that carry the spirit of nationalism and idealism by reformulating the governance of the natural resource sector management in the mining sector by replacing Law Number 11 of 1967 with Law Number 4 of 2009 concerning Coal Mining and Minerals which 
was later amended by Law Number 3 of 2020 concerning Amendments to Law Number 4 of 2009 concerning Mineral and Coal Mining. The primary purpose is for the Government of Indonesia to obtain as much revenue as possible from natural resources, especially the mining sector for the benefit of the country's foreign exchange so that it is beneficial for all people. It is very unfair if the Indonesian people as the owner of natural resources are so abundant, but only get a very disproportionate and disproportionate share, even the next generations will only inherit the remnants of worthless mining land. On the other hand, foreign corporations earn huge amounts of income each year for such a long period.

One of the mandates of the Mineral and Coal Mining Law is to change the concept of a mining contract of work with a Special Mining Business Permit (IUPK). Given the fundamental law of mineral and coal mining laws, the Indonesian government has aggressively pushed domestic and international companies (multinational companies) to change work contracts into IUPK. Freeport is no exception. But it was not easy to change the contract of the work to IUPK because the KK had been compromised by both sides. Freeport always uses the Pacta Sunt Servanda principle which is considered a universal principle, where the agreement that has been agreed is firmly binding as law to the parties so that one party cannot simply override the mutually agreed contract. Arbitrarily forcing a contract release could be a reason for Freeport to bring a dispute to the International arbitration forum. The Indonesian government is now ready to renegotiate.

Six important issues continue to be carried out in renegotiations between the Government of Indonesia and Freeport after the enactment of the Mineral and Coal Mining Law, first, the narrowing of the mining area including the exploration area from 212,950 hectares to 90,360 hectares (PT. Freeport Indonesia). Second, state revenues include taxes and royalties and non-tax state revenues (PNBP). Third, the divestment of shares with the ownership of the Government of Indonesia can reach $51 \%$ of the controlling shareholder. Fourth, the use of goods and services by prioritizing domestic potential. Fifth, the construction of a smelter so that mining products can be purified domestically and no longer export raw concentrate abroad. Sixth, the extension of the contract of work.

The long road of renegotiation between the Government of Indonesia and Freeport in the Joko Widodo regime showed its results when the Indonesian Government and Freeport officially signed a Head of Agreement (HoA) as a path to share divestment in July 2018. HoA is a basic agreement regarding cooperation and transactions that equivalent to the term Heads of Terms or Letter of Intent. 
First, HoA agreed on the price and structure of the Government of Indonesia to make PT. Inalum is the state mining holding company to divest Freeport shares (Inalum Corporate, Interview, 19 November 2019). HoA is the first step of the next steps of the agreement which will legally bind the related parties to control the majority of share ownership of 51 percent.

The big umbrella in the renegotiation policy on natural resource management in Indonesia is article 33 paragraph (3) of the 1945 constitution. The use of this article is carried out with the approach that natural resources are controlled by the state and are the common property of the Indonesian people which are used to achieve prosperity sustainably. Therefore, the management is entrusted to the central government and local governments as state administrators. The Indonesian government has a very strong desire to become the controlling party of the mining company Freeport, which is the largest producer of minerals, especially copper and gold, in the world. By owning a majority stake of up to 51 percent, Indonesia has the flexibility and authority to manage natural resources or in other words, is sovereign in the management of mines that have an economic value of billions of dollars so that all profits obtained will be used as much as possible for the prosperity of its people as mandated by the constitution contained in article 33 of the constitution.

Freeport mine management has become an intellectual discourse both at domestic and international levels. The more twists and back-to-back roads between the Indonesian government and Freeport have always been contentious. Ahmad Redi describes that since the 2009 release of the Number 4 constitution on mineral mining and coal, the regulation of mineral and coal industries has been in keeping with Pancasila and the 1945 constitution, but since the mineral and coal laws are only able to reach out to the legal action of the previous mining and coal legislation, they have not been able to access the existing lease laws before the mining and coal law. On the other hand, Freeport's lease existence is not consistent with Pancasila that is the fifth "social justice for all people of Indonesia" and article 33 verses (3) the 1945 constitution earth's substance, water, and natural resources are "state-controlled" and "used to the greatest extent of people's prosperity." Therefore, efforts to adjust Freeport's Contract of Work to the values of Pancasila and the 1945 Constitution are carried out through renegotiation of the Freeport Contract of Work based on the principle of "hardship" in the UNIDROIT Principles of International Commercial Contracts and the principle of natural resources for the national interest and the welfare of the people as stated in the General Resolution Assembly Resolution 1803 (XVII) of 14 December 1962, "Permanent Sovereignty Over Natural Resources (Redi, 2016). Ali Imron explained that if after the contract was made, the factual 
situation changed fundamentally, according to the provisions of Article 6.2.2 of the UNIDROIT Principles of International Commercial Contracts (UPICCs), then the ongoing contract can be reviewed. The review of the contents of the Contract of Work is to restore the disturbed balance (Hasan, 2009).

In a different perspective, Rifai-Hasan views the existence of Freeport positively in Papua. In his analysis, he explains that Freeport has contributed to sustainable development and poverty reduction in Papua. Freeport's mining operations are seen as a multiplier effect in driving the economy in Papua. Not only that, but Freeport is also able to bring together development in Papua that is economically, socially, and environmentally strong so that the economic progress of Papua and Indonesia is one of them contributed by Freeport's mining operations (Hasan, 2009). Likewise, Denise Leith in an article entitled "Freeport and the Suharto Regime (1965-1998) saw the importance of Freeport mining as a political force in Jakarta and Jayapura, involving military forces. Suharto made Freeport part of his patron of power. With his military strength, Suharto succeeded in placing Freeport as a justification for the Indonesianization and political control over Papua. This is what makes Freeport not only about the economy but also about the New Order regime's political power (Leith, 2002).

From the human rights perspective, Chris Ballard's study in "Human Rights and the Mining Sector in Indonesia: A Baseline Study" found violations committed by Freeport in Papua. In his presentation, since the beginning of Freeport's operations in Papua, the Amungme tribe has rejected Freeport's mining operations. The protests by the Amungme tribe were then mediated by the military. However, the military tends to defend Freeport, which has an impact on the interests of the Amungme tribe. In his analysis, Chris Ballard said that Freeport's mining operations had damaged the settlements of the Amungme tribe, so they had to relocate to a lower place. environmental damage and loss of local people's livelihoods are also serious impacts of Freeport's mining operations (Ballard, 2002). A similar analysis was also carried out by Glenn Banks in "Mining and the Environment in Melanesia: Contemporary Debates Review". Freeport's conflict with the Amungme tribe that resulted in human rights violations can be categorized as international violations (Banks, 2002).

This study differs from previous studies which have analyzed the legal, political, and human rights aspects of Freeport's mining operations which were carried out between 1967 and 2009 after the Mineral and Coal Mining Law was issued. This study is more specific in analyzing the renegotiation of Freeport's contract of work, especially from the aspect of state sovereignty in natural resource policies, especially Freeport's mining. 


\section{B. METHODS}

This study is socio-legal research (Banakar \& Travers, 2005) that analyzes the laws of political fists and power. This research data source is the policy of the Indonesian government for the management of its foreign investment policies, such as the 1945 constitution, the act number 1 of 1967 on foreign investment, the act of number 11 of 1967 on public mining requirements, the act number 4 of 2009 on mining and mineral mining, Constitutional court ruling number 002/ PUU-I /2003, and Constitution Court decision number 36/ PUU-X /2012. In addition, the study included Inalum Corporate interviews to sharpen analysis (Maxwell, 2005). The data collected is analyzed using a legal analysis, which is an aspect of the coherence of the work's contract renegotiating with the norms and principles of law. Political analysis was also conducted by exploring the national political interests of the Indonesian government in terms of a renegotiation agreement of work.

\section{Theoretical Basis}

The theoretical approach emerging from the development of foreign investment and mining industries in Indonesia since ancient times is not independent of the laws, politics, and sovereignty. The study analyzed Freeport's renegotiation of contracts by using the theory of sovereignty that was then connected with politics and law. Therefore, the theory of sovereignty does not stand alone in explaining Freeport's renegotiation of contracts because it will be in contact with the laws and political interests of the nation.

The concept of sovereignty is a post-medieval idea that became the main idea of law and politics throughout the world. Historically, sovereignty emerged in the 16th and 17th centuries in Europe. Historical events, such as King Henry VIII (England) asking parliament to draft a law giving the church power to the king and his descendants and immunity from foreign law and foreign authority (Jackson, n.d.). Sovereignty is a historical innovation of political and religious actors in Europe to break away from submission to the Pope and oppressive authorities (Kings) while at the same time building independence from religious and political authority. Sovereignty then became an idea developed in the modern age. Sovereignty is a way of disengaging from outside orders (Jackson, n.d.).

The theory of sovereignty has long been debated by philosophers, such as Jean Bodin (1530-1596), Thomas Hobbes (1588-1679), John Locke, Jean Jacques Rousseau and Hegel (1770-1831). In their view, the theory of sovereignty 
emerged as a way to identify and analyze the center of power in society. Sovereignty is unrestricted power, even by the constitution (Sabine, 1973). Sovereignty is, therefore, absolute authority attached to one, group, or state. The French Revolution of 1789 has profoundly affected the development of the theory of sovereignty (Leibholz, 1965). Levin called the theory of sovereignty inspired by the French collapse of feudal feuds and the emergence of capitalism based on individualism. As it is known, before the French revolution the nobles and Kings had a rule of law and politics under their rule. But, as people developed a sense of individual rights, absolute kingly power was then limited, especially by the constitution (Sandje, 2013). The most important element of sovereignty is freedom. Without freedom, the state would not be able to rule with its authority.

Moreover, the main base of sovereignty is the nationalism to which sovereignty belongs. The demands of countries' independence always lie under the umbrella of nationalism. Particularly developed nationalistic ideologies in other countries brought significant influence on sovereign consciousness. Thus, the state's theory of sovereignty always centers on two characters: (1) internal supremacy, which is inherent in its territory, and (2) external independence, independence from international relations with other countries. Charles G. Fenwick called it the undivided authority of all and independent from other countries' control (Fenwick, 1967). The ideal shape of later national sovereignty is not only about power, but also about the highest legal and moral authority (Bosanquet, 1899).

In international law of the state is interpreted as a country that is parallel to other countries and is not subject to the control of other countries. In this context, the theory of state sovereignty is placed in the basic concept of modern international law. This is where the debate is about the restoration of state sovereignty. D. Levin, A. N. Talalayev, Yu. M. Kolosov, and H. M. Velyaminov argue that the International Agreement limits state sovereignty. This opinion turned out to be rejected by V. A. Vasilenko, I. I. Lukeukuk, and V. S. Shevtsov who widely reverse that international law does not limit the reinforcement. More moderate opinions are delivered by Karen Gevorgya that the countries that do the International Agreement mean carrying out their sovereignty while limiting their sovereignty. This shows the sovereignty of a country does not stand alone because it relates to the sovereignty of other countries.

Therefore, countries based on their sovereign authority to manage their territory and relate to other countries. State authorities in implementing its sovereignty still refer to public laws and regulations. Thus, the sovereignty of the state in the exercise of its power is subject to the obedience of the state to both 
national and international laws and the public interests of a nation. The appeal between adherence to law and the manifestation of public interest will test the existence of national sovereignty in the exercise of its policies.

\section{RESULTS AND DISCUSSION}

\section{Freeport Mining in Papua}

Freeport McMoran (FCX) was a prominent international company founded in 1912, moving in the mining field of world headquarters in phoenix, Arizona, United States (Freeport McMoran). The largest copper-producing company in the world is mining in Grasberg, Papua, Indonesia, the southwestern deserts of the United States, in North America and South America, which has a large scale in Arizona and Cerro Verde in Peru (Freeport McMoran). The operation of the FCX mine began in 1967 with the mine of gold, operating the open-pit mines in 1988, and the development of underground mines since 2016 (PT. Freeport Indonesia).

Mining in Indonesia is not something strange when the Indonesian government hands over mining in Timika, Papua Province to Freeport, because Indonesia does not have human resources, capital, and high technology to mine. It is a necessity in the management of mining in Timika involving foreign parties, complemented by a commitment to cooperation between the two parties. In this case, the agreement was formulated in the contract of work between Freeport and the Government of Indonesia, represented by the Minister of Mines and Energy in April 1967. Freeport's entry into the Timika region of Papua Province was supported by the enactment of Law Number 1 of 1967 concerning Foreign Investment (PMA Law) in January 1967.

The material for the 1967 PMA Law was prepared by New Order officials assisted by the American consulting firm Van Sickle Associates since September 1966. At that time, Indonesia was still led by President Soekarno. Foreign investors and Freeport did not like Sukarno's leadership which was considered anti-capitalist and anti-colonial. When Soekarno was forced to hand over his power to Suharto, foreign investors and Freeport used the momentum to enact the 1967 PMA Law. Freeport's Contract of Work became the first Contract of Work signed under the PMA Law on 5 April 1967. The 30-year Contract of Work was signed by the Minister of Indonesian Mining, Slamet Bratanata, President of Freeport, Robert Hill, and President Director of Freeport, Forbes Wilson (Ventura, 2017). The Contract of Work is an avenue for foreign investors to initiate activities to start business activities in the mining and energy sector in Indonesia, which originated from the ideas of Freeport itself at the behest of the Suharto 
government (Hasiman, 2019). In addition to the 1967 PMA Law, the 1967 Law on General Mining Provisions also serves as a guide for the formation of a contract of work.

It is undeniable that Indonesia, which has extraordinary natural resources, also has shortcomings in managing these natural resources, both in terms of capital and human resources. Therefore, Indonesia cooperates with foreign countries to be able to manage its natural wealth with the profits being shared between the two parties concerned. However, not a few collaborations that have been established in various fields of managing Indonesia's natural resources have caused controversy, including with Freeport's cooperation, particularly the management of gold mines in the Papua region.

So far, the Papuan gold mine managed by Freeport is known as the exploitation of natural resources that is carried out without stopping, so that it is considered unfair and detrimental to the people. This condition is considered a robbery which is legalized by the Indonesian government. This is evidenced that since the beginning Freeport has experienced rejection from the Indonesian people, especially Papuans. Investment and development were used as an excuse by the government at that time without thinking about the future of Indonesia's economy.

The new order of business has been made available in the second quarter of 2007. Freeport had clapped the economy onto him. Though a signed contract contradicts the 1945 constitution, Indonesia needed foreign capital to build a country, but it was not right to explore indigenous land with unjust contracts and the 1945 constitution.

\section{Divestation of Freeport}

The existence of state sovereignty depends on the ownership of Freeport shares where the majority share is not owned by the Government of Indonesia. Article 112 confirms the holders of Mining Business Permits (IUP) and Special Mining Business Permits (IUPK). After 5 (five) years of production, foreignowned shares are required to divest shares in the Government, regional government, state-owned enterprises, regional-owned enterprises, or national private enterprises. In its effort to follow up the provisions of Article 112 of the 2009 Mineral and Coal Mining Law, the Government stipulates Government Regulation Number 23 of 2010 concerning the Implementation of Mineral and Coal Mining Business Activities. In Government Regulation Number 23 of 2010, the number of shares that must be divested to Indonesian participants is at least 
$20 \%$. Two years later, the government changed Government Regulation Number 23 of 2010 with Government Regulation Number 24 of 2012 concerning Amendments to Government Regulation Number 23 of 2010 concerning the Implementation of Mineral and Coal Mining Business Activities. One of the important changes contained in Government Regulation Number 24 of 2012 concerning the size of shares that must be divested to be at least $51 \%$ (Government Regulation Number 24 of 2012 concerning the Implementation of Mineral and Coal Mining Business Activities, 2012). This increase in the percentage of shares that must be divested is intended to provide greater opportunities for the Government of Indonesia to participate more in mineral mining business activities. Two years later, Government Regulations Number 77 of 2014 concerning the third amendment to Government Regulation Number 23 of 2010 concerning the Implementation of Mineral and Coal Mining Business Activities which reaffirms the obligation to divest shares of 51 percent in the tenth year (Government Regulation Number 77 of 2014 concerning the Implementation of Mineral and Coal Mining Business Activites, 2014).

Freeport's divestment of shares is an obligation regulated in the Mineral and Coal Mining Law (Negara Republik Indonesia, 2009), and its implementing regulations, namely Government Regulations Number 1 of 2017 re-emphasizes that gradually with details of the divestment of its shares, in article 97 paragraph (1) that the holders of IUP and IUPK in the context of foreign investment, after 5 (five) years from production are obliged to divest their shares in stages, so that in the tenth year its shares are at least $51 \%$ owned by Indonesian participants. The ownership of Indonesian participants as referred to in paragraph (1) in each year after the end of the fifth year since production cannot be less than the percentage as stipulated in article 97 paragraph (2), namely (Government Regulation Number 1 of 2017 concerningthe Implementation of Mineral and Coal Mining Business Activites, 2017) in the sixth year 20\%, seventh year 30\%, eighth year $37 \%$, the ninth year $44 \%$ and the tenth year $51 \%$. The share that should have been owned by the government since 2010 is $20 \%$. However, in reality, until the Freeport share divestment agreement was reached, the government only obtained 9.36 percent.

For years Freeport has been in the hands of foreign countries and now they should be proud because without the pressure of hard power diplomacy, but soft power diplomacy negotiations, the Indonesian government managed to "tame" Freeport McMoran through the divestment agreement of 51 percent of Freeport Indonesia's shares. Through the very long process of renegotiating the Freeport divestment between the Government of Indonesia and Freeport, finally during the Joko Widodo administration, there was a breath of fresh air when in July 2018, 
the Indonesian government and Freeport officially signed HoA as a way to divest the shares. Head of Agreement is a basic agreement regarding cooperation or transaction which is equivalent to the term Heads of Terms or Letter of Intent. Then the Indonesian government encouraged Inalum Corporate as a government-owned mining holding company to divest Freeport shares. The Head of Agreement is the first step of the next steps of the agreement which will legally bind the related parties to control the majority of share ownership of $51 \%$. This agreement is legally binding on the parties through the purchase of Rio Tinto shares worth US\$ 3.85 billion. The fee will be used to purchase Rio Tinto's Participating Interest and 100 percent of FCX's shares in PT Indocopper Investama. Rio Tinto's participating interest in PTFI is 40 percent, while Indocopper's shares are 9.36 percent (Inalum, Interview, 19 November 2019).

The peak was on September 9, 2018, the Indonesian government officially took over Freeport's 51\% stake. The finalization of the Freeport share divestment took place at the Ministry of Energy and Human Resources office. The process of divesting $51 \%$ of Freeport's shares to the government was officially agreed, after the Mining Industry Holding Inalum Corporate, Freeport McMoran Inc. (FCX), and Rio Tinto signed the Freeport Divestment Agreement, the Rio Tinto Indonesia Corporate (PTRTI) Shares Sale and Purchase Agreement and the Freeport Shareholder Agreement. With the signing, the number of Freeport shares owned by Inalum Corporate increased from $9.36 \%$ to $51.23 \%$ and the Provincial Government of Papua acquired 10\% of 100\% of Freeport's shares (Public Relations Secretariat of the Republic of Indonesia, 2015).

The contents of the Freeport share divestment agreement contain four points. First, share divestment of 51 percent for the ownership of Indonesian participants, following the contract of work and Law Number 4 of 2009 concerning Mineral and Coal Mining. Second, the construction of processing and refining facilities (smelters) for 5 years. Third, the stability of state revenues under Article 169 of the Mineral and Coal Mining Law, the transfer of Freeport's contract of work to IUPK will provide state revenues that in the aggregate are greater than state revenues through the Contract of Work. Fourth, the extension of production operations for $2 \times 10$ years, following the provisions of the legislation. After Freeport agrees on the four points above, Freeport will get an extension of the maximum operating period of 2 x 10 years until 2041 (Ministry of Energy and Mineral Resources, 2018).

The government's decision on the success of Freeport's divestment has drawn praise and criticism. On the praising side, the government has made great achievements after the twists and turns of the Freeport divestment journey that 
has been going on for almost 3 decades. Finance Director of Inalum Corporate Orias Moedak Corporate assures that it will not take long for Inalum to return the investment. This is because by holding $51.23 \%$ of Freeport's shares, Inalum Corporate is projected to reap dividends of around US\$ 1 billion per year. However, according to Orias, such a large dividend will not be immediately obtained by Inalum Corporate in 2019. Orias believes, in 2022 Inalum Corporate can benefit from dividends of around US $\$ 1.3$ billion. From the calculation of the dividend distribution, Orias assures that Inalum Corporate will have no trouble paying global bonds of US\$ 4 billion. Because, if calculated, Inalum Corporate received dividends of around US\$ 1 billion from 2022, so by 2025, the dividends obtained by Inalum Corporate have exceeded loans from global bonds of US $\$ 4$ billion. The scheme for the amount of Inalum's global bond payment will follow the agreed tenor and continue to decrease according to the arrangement that has been repaid. Meanwhile, global bonds issued by Inalum Corporate covers four tenors. First, funds worth US\$ 1 billion were obtained with a $5.23 \%$ coupon maturing in 2021. Second, US $\$ 1.25$ billion with a $5.71 \%$ coupon with a tenor until 2023 . Third, worth US $\$ 1$ billion with a $6.53 \%$ coupon maturing in 2028 . Fourth, worth US\$ 750 million with a 6.75\% coupon with a tenor until 2048 (Mulyana, 2018).

However, several observers and economists criticized Inalum's corporate action to divest $51 \%$ of Freeport's shares. Energy and Natural Resources Observer at Tarumanegara University, Ahmad Redi, assessed that the policy of purchasing divestment shares at the expiration of the Contract of Work is a policy that harms Indonesia because without buying divested shares, in 2021 or after the contract of work ends, the former Freeport area belongs to the government of Indonesia (Zuraya, 2017).

Said Didu, former Secretary of the Ministry of SOEs assessed that there was injustice in the divestment of $51 \%$ shares. According to him, Freeport has at least five advantages from this divestment action. First, they received fresh funds of Rp 55 trillion. They also have controlling rights even though they only have minority shares. In addition, Freeport has also received assurances on contract extensions until 2041, tax certainty, and the possibility of being free from the threat of environmental fines. This is because the majority of shareholders are now Indonesian. According to him, the acquisition of Freeport shares using debt is not a good decision. Moreover, the ones assigned to borrow are SOEs. As a result, the number of SOEs that are burdened by assignments is increasing (Gumiwang, 2017). 
Furthermore, the former Coordinating Minister for Maritime Affairs, Rizal Ramli criticized Inalum Corporate and questioned why Freeport still received an economic interest of $81.28 \%$ until 2022. Meanwhile, until 2022, Inalum Corporate only gets $18.74 \%$ economic interest. Previously he also criticized the divestment of Freeport's 51\% shares, because basically the Freeport contract signed in 1991 was legally flawed and did not adhere to the sanctity of contract principle (the sanctity of the contract) so there was no obligation to agree to a 2x10 year extension of Freeport's contract until 2041. many defaults, environmental damage, and the construction of smelters that are continuously postponed, as well as a track record of bribing Indonesian officials (Budiartie, 2018).

The acquisition of Freeport's shares of up to 51 percent deserves appreciation. However, the consequences that arise also need to be considered, especially regarding debt, natural damage and human rights violations. Of course, don't let the acquisition of these shares add to other problems for state sovereignty.

\section{Change of Contract Regime}

The contract of work is a contract between the Government of the Republic of Indonesia and a Foreign Investment Company (PMA) 1967. The contract of work contains financial technical requirements and other requirements to carry out mining business activities for Indonesian minerals, except oil and gas, coal, and uranium (Saleng, 2004). The Contract of Work is something that benefits Freeport. The contract became a legal tool for Freeport to make a lot of money out of copper and gold in Erstberg, Grasberg, and the underground mines in Papua. With a paper contract, Freeport could do more business expansion and explore Papua's copper and gold. Ironically, the contract was thought of by Indonesian Freeport and President Suharto. The reason for the contract work is that the investment in Erstberg in those years was costly (Mealey, 1999).

Indonesia as the host has the right to participate in the arrangement of the contract of work. The position of the Government as a regulator becomes a direct force in the interests of the state and for the welfare of the people. The state does not take part in making the contract of work. The state only opens the investment faucet under the pretext of economic development. Whereas the main task of the state is to regulate the wheels of the economy and limit business people from being greedy. The state should be present in drafting regulations so that corporations are not reckless in exploiting nature and seeking profit, ignoring the environment and the prosperity of the people (Hasiman, 2019). In other words, 
the state should be present and make efforts to restore state sovereignty as stated in Article 33 of the 1945 Constitution paragraph (2), "Production branches which are important for the state and which affect the livelihood of the people are controlled by the state" and paragraph (3), "Earth, water and natural resources contained therein are controlled by the state and used for the greatest prosperity of the people" (Rakhmawati, 2003).

Indonesia uses the contract of work concept in the mining sector, where the state is positioned as a business actor as regulated in the 1967 Basic Mining Provisions. In line with the enactment of the Mineral and Coal Mining Law, the contract of work must be changed to a Special Mining Business Permit (IUPK). The Law on Mineral and Coal Mining stipulates that the contract of work must end because it is considered unfair to the state and people of Papua. However, it seems that the Government has not completely abolished the provisions of the existing contract rules. This can be seen in Article 169 point a of the Mineral and Coal Mining Law which still recognizes the existence of a contract of work: "the contract of work and the agreement of work for coal mining exploitation that existed before the enactment of this law shall remain in effect until the expiration of the contract/agreement". This provision certainly raises the uncertainty of the government's position in terms of mining management. Although in this case, the government has a higher position, the recognition of the existence of the contract of work is the government's indecision in changing the licensing regime for natural resource management in Indonesia (Nefi et al., 2018). However, the Minister of Energy and Mineral Resources issued Regulation of the Minister of Energy and Mineral Resources Number 5 of 2017 concerning Increasing the Added Value of Minerals through Domestic Mineral Processing and Refining Activities. Article 17 of the Minister of Energy and Mineral Resources Number 5 of 2017 stipulates that the holder of the contract of work can sell the processing results abroad in a certain amount for a maximum of five years provided that the form of mining business changes into a Special Mining Business License for Production Operations and pays export duties and fulfills the minimum processing limit (Ministry of Energy and Mineral Resources, 2017).

The conversion of the Contract of Work to IUPK is certainly something that is not pleasant for Freeport. Since the enactment of the Mineral and Coal Mining Law, Freeport has continued to argue that the company's mining business is still based on the contract of work (Hasiman, 2019). The government of Susilo Bambang Yudhoyono, which has tried to renegotiate the contract, has also repeatedly found a dead end because Freeport has always been hiding behind a contract of work. Why not, with the conversion of the contract of work into an IUPK, Freeport is obliged to divest $51 \%$ of its shares to the national party, build 
a smelter factory, and raise taxes. Consequences like this are certainly not easy for Freeport. So far, Freeport McMoran controls 91\% of Freeport's shares, and the remaining $9 \%$ is owned by the government through BUMN.

Therefore, Freeport has taken various measures to ensure that the contract of work remains the basis for its business expansion. Freeport has repeatedly threatened to sue the Indonesian government in international arbitration. On the other hand, the government itself seems afraid because if production falls, state revenues will also decrease so that the trade balance can suffer losses. At that time, President Susilo Bambang Yudhoyono was very careful to maintain the stability of Indonesia's macroeconomic posture so that it would not be attacked by political opponents and considered as a failed regime. In fact, President Susilo Bambang Yudhoyono's move is a boomerang. Fear of being attacked by political opponents made the conversion of the contract of work into an IUPK following the order of the Mineral and Coal Mining Law failed to be implemented. The risk is that the state becomes not sovereign over natural resources. The 1945 Constitution affirms that the task of the state is to control mining wealth for the welfare of the people.

However, during the Joko Widodo administration, there was a significant change through contract renegotiation with Freeport. The Indonesian government has agreed with Freeport to divest $51 \%$ of its shares so that the majority share ownership is held by the Indonesian government through Inalum corporate. This agreement resulted in the extension of Freeport's mining operations in Papua and put Freeport in a position to obtain a mining permit in the form of an IUPK, no longer a contract of work (Inalum, Interview, 19 November 2019).

Another strategic policy is the issuance of Law Number 3 of 2020 concerning amendments to Law Number 4 of 2009 concerning Mineral and Coal Mining. The revision of the Mineral and Coal Mining Law guarantees the continuation of the Coal Mining Concession Contract of Work/Work Agreement (PKP2B) to become an IUPK as a Continuation of Operations taking into account efforts to increase state revenues. Not only Contracts of Work and PKP2B that get guarantees for the continuation of operations, holders of Mining Business Permits (IUP) and Special IUPs (IUPK) also breathe the same fresh air. In the old Mineral and Coal Mining Law, the extension of the permit was stated with a "can be extended" clause, which was replaced with "guaranteed" in the revision of this Law. This can be seen in Article 47, Article 83, and Article 169, Article 169 A.

Article 47 letter $\mathrm{f}$ states: "For metallic mineral mining which is integrated with processing and/or refining facilities for 30 (thirty) years and guaranteed to 
obtain an extension for 10 (ten) years each time the extension meets the requirements by the provisions of the legislation. Article 83 letter $h$ also confirms: "The period of Coal Production Operation activities that are integrated with coal development and/or utilization activities are given 30 (thirty) years and guaranteed to get an extension of 10 years each time an extension after fulfilling the requirements by with the provisions of the legislation". Similarly, Article 169 A paragraph (1) letter a states: "contracts/agreements that have not yet obtained an extension are guaranteed to get 2 (two) extensions in the form of IUPK as continuation of operations for each contract/agreement for a maximum period of 10 (ten) years as a continuation of operations after the expiration of the KK or PKP2B by considering efforts to increase state revenues."

With this legal policy, Freeport is guaranteed an extension on mining operations in Papua. The policy seems to give Freeport a red carpet in mining. Because Freeport's shares are already controlled by the Indonesian government, the guarantee for the extension of mining operations does not conflict with the constitutional mandate in controlling natural resources. However, for foreign companies, it will be detrimental to the Indonesian people in the mining management of natural resources.

\section{CONCLUSIONS}

The policy of renegotiating the management of natural resources in Indonesia is article 33 verses (3) of the 1945 constitution with the approach that natural resources are the state-controlled and common property of the Indonesian people used to achieve the prosperity of the people. Since the rights of natural resources are at the hands of Indonesian people, it is entrusted to governments and local governments as national administrators. Therefore, the government has officially taken over Freeport shares by $51 \%$ as part of a country's sovereignty over the management of its natural resources. With the majority of its shares owned by the Indonesian government, freeport management is no longer based on a contract of work, but an IUPK. This has changed the form of mining resource exploitation from a contractual pattern to a licensing pattern so that the Indonesian Government is in a higher position than foreign entrepreneurs. Thus, the state is sovereign over the management of its natural resources. 


\section{REFERENCES}

Ballard, C. (2002). Human Rights and the Mining Sector in Indonesia: A Baseline Study. IIED and WBCSD.

Banakar, R., \& Travers, M. (2005). Theory and Method in Socio-Legal Research. Onati: Hart Publshing Oxford and Portland Oregon.

Banks, G. (2002). Mining and the Environment in Melanesia: Contemporary Debates Reviewed. The Contemporary Pacific.

Bosanquet, B. (1899). The Philosophical Theory of the State. Macmillan.

Budiartie, G. (2018). Freeport Critic, Rizal Ramli Claims There's a Way Out of The Box. cnbc Indonesia. https://www.cnbcindonesia.com/news/20181227161728-4-48215/kritikfreeport-rizal-ramli-klaim-ada-cara-out-of-the-box

Fenwick, C. G. (1967). International Law.

Freeport McMoran. (n.d.-a). INDONESIA | Freeport-McMoRan.

Freeport McMoran. (n.d.-b). OVERVIEW I Freeport-McMoRan.

Gumiwang, R. (2017). Measuring Plus Minus Acquisition of 51 percent Freeport Shares. Tirto.id. https://tirto.id/mengukur-plus-minus-akuisisi-51-persensaham-freeport-dc7e

Hasan, P. A. R. (2009). Development, Power, and the Mining Industry in Papua: A Study of Freeport Indonesia. Journal of Business Ethic, 143.

Hasiman, F. (2019a). Business of Strong People vs. State Sovereignty. In Kompas.

Hasiman, F. (2019b). Business of Strong People vs. State Sovereignty. PT. Gramedia.

Hertanto, A. W. (2003). Contract of Work: A Study of Civil Law. Journal of Law and Development, 38(2), 199.

Jackson, R. (n.d.). Sovereignty: The Evolution of an Idea. Polity Press.

Leibholz, G. (1965). Politics and Law. A.W.Sijth Off.

Leith, D. (2002). Freeport and the Suharto Regime (1965-1998). University of Hawai'i Press.

Maxwell, J. A. (2005). Qualitative Research Designan Interactive Approach. Page Publication.

Mealey, G. A. (1999). copper and gold mining in the mountains of Irian Jaya in the 
most remote deposits in the world. Freeport-McMoran Copper and Gold.

Ministry of Energy and Mineral Resources. (2017). See Regulation of the Minister of Energy and Mineral Resources Number 5 of 2017 concerning Increasing Value Added Minerals through Domestic Mineral Processing and Purification Activities.

Ministry of Energy and Mineral Resources. (2018). Signed, This is the Contents of the Divestment Agreement of 51 Percent of Freeport's Shares to Inalum. Bareksa.

https://www.bareksa.com/berita/id/text/2018/07/12/ditandatangani-ini-isiperjanjian-divestasi-51-persen-saham-freeport-ke-inalum/19753/news

Mulyana, R. N. (2018). This is the calculation of Inalum's global bond dividends and payments after acquiring Freeport. Kontan.co.id.

https://industri.kontan.co.id/news/begini-hitungan-dividen-danpembayaran-global-bond-inalum-setelah-punya-freeport

Nefi, A., Malebra, I., \& Ayuningtyas, D. P. (2018). Implications of the Enforcement of the Contract of Work of PT. Freeport Indonesia after Law no. 4 of 2009 concerning Mineral and Coal Mining. of Law \& Development, 48(1), 140.

Negara Republik Indonesia. (2009). UNDANG-UNDANG NOMOR 4 TAHUN 2009 TENTANG PERTAMBANGAN MINERAL DAN BATUBARA.

Government Regulation Number 24 of 2012 concerning the Implementation of Mineral and Coal Mining Business Activities, (2012).

Government Regulation Number 77 of 2014 concerning the Implementation of Mineral and Coal Mining Business Activites, (2014).

Government Regulation Number 1 of 2017 concerningthe Implementation of Mineral and Coal Mining Business Activites, (2017).

PT. Freeport Indonesia. (n.d.-a). Details of the Contract of Work Amendment Agreement.

PT. Freeport Indonesia. (n.d.-b). PT Freeport Indonesia.

Public Relations Secretariat of the Republic of Indonesia. (2015). Divestment Agreement Signed, Indonesia Legally Becomes the Owner of Freeport's Subscription Shares. https://setkab.go.id/perjanjian-divestasiditandatangani-indonesia-sah-jadi-pemilik-saham-mayoritas-freeport/

Rakhmawati, R. (2003). Investment Law in Indonesia in Facing the Global Era. 
Bayumedia Publishing.

Redi, A. (2016a). PT Freeport Indonesia's Contract of Work in the Perspective of Pancasila and the 1945 Constitution. Journal Constitution, 13(3), 630-631.

Redi, A. (2016b). PT Freeport Indonesia's Contract of Work in the Perspective of Pancasila and the 1945 Constitution. Journal Constitution, 13(3), 614.

Sabine, G. H. (1973). A History of Political Theory. Dryden Press.

Saleng, A. (2004). Law of Mining. UII Press.

Sandje, R. N. (2013). Etat et nation dans le constitutionnalisme africain: étude thématique. Université de Bourgogne.

Ventura, B. (2017). History of Freeport in Indonesia 2: Ertsberg and Andil Julius Tahija. Sindonews. https://ekbis.sindonews.com/berita/1183287/34/sejarahfreeport-di-indonesia-2-ertsberg-dan-andil-julius-tahija

Zuraya, N. (2017). Indonesia does not benefit from the agreement with Freeport, this is the reason. Republika.co.id.

https://www.republika.co.id/berita/ekonomi/makro/17/08/29/ovfwqtindonesia-tidak-mendapat-keuntungan-dari-kesepakatan-denganfreeport-ini-alasannya 